\title{
Islam and the Abolition of Slavery
}

\author{
William Gervase Clarence-Smith
}

New York: Oxford University Press, 2006. 293 pages.

This book delves into Islam and its connection with slavery in historical and etiological terms by presenting the synthesis in an almost axiomatic manner that "slavery has always been a part and parcel of the basic core and a central tenet of Islam." The author relies on various scholarly sources, including the Qur'an and the hadiths, with the bulk of information coming from nonIslamic sources. Providing quotes from various scholars (e.g., Lewis, Muir, Berlioux, Hughes, Garrett, Margoliouth, Roberts, and DeJong) (pp. 16-17), Clarence-Smith brings out of a set of synergistic syllogisms on the assumptive plane that the Qur'an failed to eliminate slavery, that removing this practice would shake the faith itself, that the Prophet was totally unaware of the concept of abolition as an idea as well as in practice, and, importantly, that the whole Islamic social structure with its attendant system was based on a type of slavery associated with the organization of the harem.

Hence, from the author's point of view, Islam in essence kept slavery within a massive infrastructure and played a negligible role in its demise. Moreover, the system was abolished mostly due to western effort rather than any purely religious guidelines or impetus. This organized form of slavery included singing girls, concubines, common soldiers from the ranks of war captives as well as non-war captives, cannon fodder, bond maidens, harem guards, and chattel similar to livestock - collectively often reaching into the millions. While there were examples of slaves rising to the position of amir, such instances are exceptions and extremely rare.

The author defends his argument's basic propositions in eleven highly condensed chapters. The first chapter, "Introduction," basically details his central thesis with supporting arguments, including the intensity of the slave systems as highlighted above. The concluding segment, "Envoi," outlines the current responsibilities of different religious groups for a greater cooperation and unity toward the process of slavery's final elimination and apologizing for past misdeeds.

In the second chapter, Clarence-Smith argues that despite some efforts to stop slavery by Sunni scholars and rulers within the Shari'ah's framework, the efforts failed due to the fragmented arguments. In the same way, the author asserts in the third chapter that Sufi traditions, by focusing more on the inner jihad (struggle) and promoting leniency, did not cause slavery to disappear either. In the fourth chapter, arguments are made that in the 
processes involving freedom or enslavement, occasionally local ordinances were more powerful, whereas at other times the Shari ah played a more vital role in a similar process. In the fifth chapter, the author argues that sometimes the ulama accepted or rejected locally developed laws, opposing the religious ones as suited to the situation of functionality. In the sixth chapter, Clarence-Smith states that the expansion of western imperial power, which promoted secularism in Muslim lands, did not produce very profound positive results because all parties benefited from slavery's continued existence in one way or another for various economic and political gains.

The seventh chapter argues that Muslim scholars were divided on slavery, often under western military and political pressure. However, in most cases, Islamic scholars systematically maneuvered the environment in their favor. In the eighth chapter, the author, when dealing with the growth of neoSufism and Mahdist movements and the effects of their philosophical activities in different geographical areas, shows that the approaches to addressing slavery varied, for they depended on convenience rather than ideological stance. In the ninth chapter, while addressing the Wahhabi and other movements, for example, in Egypt, Saudi Arabia, or India, he states that Islamic scholars focused more on the literal interpretation of justifying slavery in varying degrees according to the Hanbali school. The tenth chapter highlights the impact of the Mu tazili tradition, characterized by rationalism in its opposition of slavery, which produced two groups: radicals seeking instantaneous abolition, and gradualists seeking a slower pace. In the eleventh chapter, the author suggests that despite all doubts and condemnations, most religions practiced slavery under various pretexts.

In conclusion, one could suggest that the book, by some measures, can be graded as a monumental piece and a landmark study of the Islamic stance on slavery due to the mass utilization of sources to block every possible avenue of critique. In the tense climate between the West and the Muslim world arising within the last few decades, especially with regard to the issues of women's rights and terrorism, this book is expected to draw immense scholarly attention from the Islamic and non-Islamic paradigms involving the field of Islamic history in particular and history in general, sociology, justice studies, law, international relations, international human rights issues, and philosophy, just to mention a few.

In an effort to probe the pivotal propositions, all eleven chapters remained in general congruency. However, the book falls short of its ultimate goal in terms of appealing to a much larger audience in the realm of puritanical Islamic scholars who see Islam as a religion of peace within a systemic context as supported by many non-Muslim scholars. In support of 
his assertions, the author used a minimal number of Qur'anic verses and Prophetic hadith and did not demonstrate a proper understanding of Islam in structural terms. Moreover, the analyses lacked the following elements: a) a contextual component of Qur'anic verses and specific hadiths related to the Revelation, b) a portrayal of the interrelationship between various Qur'anic verses in relation to the hadith literature, c) synthetic links between various hadiths, and d) highlighting the innumerable hadiths emphasizing the humane treatment of slaves as well as encouraging their emancipation. Due to these shortcomings, as well as to not putting Islam in a comparative and teleological perspective, Islam has been presented as a cult and an evil force. Although the author did provide some comparative element in conjunction with other religions in the last chapter, this is far too late for many readers to view Islam in a neutral light.

Many people who do not have a deeper understanding of Islam would find the book very conclusive. However, without proper responses to the shortcomings highlighted in connection with the primary Islamic sources and their appropriate analyses following an Islamic methodology of probing, the book's conclusive status remains tentative. As a consequence, a new edition is highly recommended along the lines suggested.

Muhammad M. Haque 